\title{
Assessment of pharmacological activities of two medicinal plant of Bangladesh: Launaea sarmentosa and Aegialitis rotundifolia roxb in the management of pain, pyrexia and inflammation
}

\author{
Golam Sarwar Raju', Md Mizanur Rahman Moghal ${ }^{1 *}$, Mohammad Salim Hossain ${ }^{1}$, Md Mahadi Hassan', \\ Md Mustahsan Billah', Sayed Koushik Ahamed $^{2}$ and SM Masud Rana ${ }^{1}$
}

\begin{abstract}
Background: The current study aims at evaluating the analgesic, anti-pyretic and anti-inflammatory properties of methanolic extract of the stem, bark and leaves of Launaea sarmentosa and Aegialitis rotundifolia roxb.

Results: The AELS and AEAR extract presented a significant $\left({ }^{* *} \mathrm{p}<0.001\right)$ dose dependent increase in reaction time in writhing method and showed inhibition of $63.1 \%$ and $57.1 \%$ respectively at the doses of $400 \mathrm{mg} / \mathrm{kg}$ body weight while standard drug showed $(P<0.001)$ inhibition of $69.23 \%$. In tail immersion method, AELS and AEAR showed maximum time of tail retention at $30 \mathrm{~min}$ in hot water i.e. $6.93 \mathrm{sec}$ and $6.54 \mathrm{sec}$ respectively at highest doses of $400 \mathrm{mg} / \mathrm{kg}$ body weight than lower dose while standard pentazocine showed reaction time of $7.62 \mathrm{sec}$. The AELS and AEAR extract also exhibited promising anti-inflammatory effect as demonstrated by statistically significant inhibition of paw volume by $32.48 \%$ and $26.75 \%$ respectively at the dose of $400 \mathrm{mg} / \mathrm{kg}$ body weight while the value at the dose of $200 \mathrm{mg} / \mathrm{kg}$ body weight were linear to higher dose at the $3^{\text {rd }}$ hour of study. On the other hand, Standard indomethacin inhibited $40.13 \%$ of inflammation (*** $<0.001$ ). In Cotton-pellet granuloma method, AELS and AEAR extract at the dose of $400 \mathrm{mg} / \mathrm{kg}$ body weight exhibited inhibition of inflammation of $34.7 \%$ and $29.1 \%$ respectively while standard drug showed $(P<0.001)$ inhibition of $63.22 \%$. Intraperitoneal administration of AELS and AEAR showed dose dependent decrease in body temperature in brewer's yeast induced hyperthermia in rats at both doses. However, AELS significantly decreased body temperature $\left({ }^{* * *} \mathrm{p}<0.001\right)$ at $400 \mathrm{mg} / \mathrm{kg}$ compared to control.

Conclusions: Present work propose that the methanolic extract of Launaea sarmentosa and Aegialitis rotundifolia roxb possesses dose dependent pharmacological action which supports its therapeutic use in folk medicine possibly mediated through the inhibition or blocking of release of prostaglandin and/or actions of vasoactive substances such as histamine, serotonin and kinins.
\end{abstract}

Keywords: Launaea sarmentosa, Aegialitis rotundifolia roxb, Analgesic, Antipyretic, Anti-inflammatory

\section{Background}

Inflammation in response to cellular injury is a complex physiological reaction of the body that is marked by tissue swelling, capillary dilation and anti-histamine activity result in redness, heat and pain, tumor and loss of function [1]. It is generally initiated by several factors ranging from

\footnotetext{
* Correspondence: pharmizan@yahoo.com

'Department of Pharmacy, Noakhali Science and Technology University,

Sonapur, Noakhali 3814, Bangladesh

Full list of author information is available at the end of the article
}

bacterial infection and chemical injury to environmental pollution that result in apoptosis, cell injury or death $[2,3]$. Tissue injury induced by this injury or trauma results in the release of inflammatory mediators including cytokines, tumor necrosis factor (TNF- $\alpha$ ), interleukin-1 (IL-1) from leukocytes, monocytes and macrophages [4]. The cytokines further trigger the up-regulation of other pro-inflammatory cytokines, chemokines, immunoglobulins as well as increase the expression of many cellular adhesion molecules (CAMs) and their physiological action [5].

\section{Biomed Central}

(C) 2014 Raju et al.; licensee BioMed Central Ltd. This is an Open Access article distributed under the terms of the Creative Commons Attribution License (http://creativecommons.org/licenses/by/4.0), which permits unrestricted use, distribution, and reproduction in any medium, provided the original work is properly credited. The Creative Commons Public Domain Dedication waiver (http://creativecommons.org/publicdomain/zero/1.0/) applies to the data made available in this article, unless otherwise stated. 
Also there is an increase in the expression of phospholipase A2, cyclooxygenase- 2 (COX-2), 5-lipoxygenase (5-LOX) and inducible nitric oxide synthase (iNOS) $[6,7]$ which work collectively to increase vasodilatation and permeability of blood vessels $[8,9]$ and leads to increased blood flow, exudation of plasma proteins and fluids and migration of leukocytes, mainly neutrophils into the injured tissues $[10,11]$. For instance, the regulation of prostaglandin i.e. eicosanoid synthesis is a classic mechanism for controlling inflammation and pain $[12,13]$.

On the other hand, Pain is mainly a defensive mechanism of the body and is an ill-defined, unpleasant sensation and emotional experience along with acute or chronic tissue damage which is usually induced by an external or internal noxious stimuli $[14,15]$. The subsequent elaboration of mediators such as interleukin-1 and tumor necrosis factor- TNF- $\alpha$ is believed to propagate the synthesis, release and action of autacoid prostaglandin E2 (PGE2) and F2 $\alpha$ by the endothelium and pericytes of brain capillaries that excite pain nerve endings $[16,17]$. The increase in prostaglandin levels within the peritoneal cavity increases capillary permeability and thus enhances inflammatory pain [18].

Pyrexia or fever is due to secondary impact of malignancy, inflammation, tissue damage, infections or other diseased states [19]. The infected or damaged tissue initiates the secretion and enhanced formation of pro-inflammatory chemical mediators (cytokines e.g. interleukins- $1 \beta, \alpha, \beta$ and TNF- $\alpha$ ) which upsurge the synthesis of prostaglandin E2 (PgE2) near the pre-optic hypothalamic area, thereby triggering the hypothalamus activity to elevate normal body temperature $[20,21]$. Most of the antipyretic drugs acts to reduce the elevated body temperature by inhibiting COX-2 expression, thus PGE2 biosynthesis [22].

Drugs or compounds which are used currently for the management of fever, pain and inflammatory conditions are either non-steroidal like aspirin or steroidal like corticosteroids. All of these drugs also possess additional toxic side effects like allergic reactions, renal failure, hearing loss or they may rise the risk of hemorrhage by affecting platelet coagulation function [23,24]. Therefore, development of newer safe and more influential anti-inflammatory drugs with lesser side effects are necessary. Studies suggest that aromatic plant and herbs (ginger and turmeric) may block cyclooxygenase (COX) and lipoxygenase (LOX) pathways thereby inhibiting the release of prostaglandin, leukotriene and also inhibit the release of histamine [25-28].

Launaea pinnatifida Cass. Synonym L. sarmentosa (Willd.) is belong to Asteraceae family, locally known as kulhafila in the Maldives, is a creeping, perennial procumbent, stoloniferous herb, native to tropical Indian coastlines $[29,30]$. The leaflets of L. sarmentosa are simple toothed form with an average size of $12-15 \mathrm{~cm}$ long.
Leaves are slightly bitter in taste and have characteristic odor. The roots of L. sarmentosa showed the presence of lactiferous cells, pitted vessels, simple fibers, calcium oxalate crystals, devoid of pith and contains alkaloids, amino acids, glycosides, tannin, carbohydrates and steroids [29,31]. It is used by mothers after child birth mainly in a lehya preparation known as Hilibeys. It has popularity in the treatment of abdominal disorders, urinary infections [29]. L. sarmentosa is also testified to possess soporific, tonic, diuretic and aperient properties and is used as a substitute for Taraxacum [32]. Whole plant is used in rheumatoid arthritis, gout and the leaf in rheumatism and also to heal skin injuries caused by fish spines while fishing [33]. Herb of these plant are fed to buffaloes as a galactagogue [34]. Another study affirmed the use of whole plant as a bath decoction to treat skin related diseases [35].

Aegialitis rotundifolia Roxb locally known as banrua belong to Plumbaginaceae family are small trees or woody mangrove shrubs that grow up to $2-3$ meter tall and is available in the sandy or rocky soils of more saline area of Sundarbans of west Bengal and are endemic to the coastal part of South Asia [36-38]. The deciduous species have leafy stems with leathery leaves, the flowers are organized in terminal cymose racemous inflorescences forms and fruits are dehiscent and have a spongy mesocarp [39]. Locally it is pounded with oil and applied to relief insect bites pain but there is no scientific evidence to support this therapeutic use. There is no strong evidence on the use of that genus in folklore medicine and the phytochemical compounds are not so well identified.

With this background, the present study was undertaken to inspect the activity of the aforementioned traditional claims of L. sarmentosa and A. rotundifolia roxb. Thus, we investigated the analgesic, anti-pyretic and antiinflammatory effects of proposed plant on the peripheral and central nervous systems by using several validated experimental methods in trial animals. Preliminary acute toxicity test were also carried out to evaluate the safety dose range of these widely used medicinal plant.

\section{Results}

\section{Antipyretic activity test}

The results of brewer's yeast-induced anti-pyretic activity of AELS and AEAR were shown in Table 1. It was observed that $400 \mathrm{mg} / \mathrm{kg}$ of AELS showed maximum antipyretic activity by reducing the temp at of $36.38^{\circ} \mathrm{C}$ at $5^{\text {th }}$ hour while compared with standard acetyl salicylic acid that reduces the temp at $35.89^{\circ} \mathrm{C}$. On the other hand, $400 \mathrm{mg} / \mathrm{kg}$ of AEAR showed moderate antipyretic activity by reducing the temp at $36.61^{\circ} \mathrm{C}$. Figure 1 shows the rectal temperature $\left({ }^{\circ} \mathrm{C}\right),(\mathrm{P}<0.001,0.01$ and 0.05$)$ for the test and standard when compared to the control. The test drugs 
Table 1 Effects of AELS, AEAR and Standard drug on brewer's yeast induced pyrexia

\begin{tabular}{|c|c|c|c|c|c|c|c|c|c|}
\hline \multirow[t]{2}{*}{ Group } & \multirow[t]{2}{*}{ Treatment } & \multirow{2}{*}{$\begin{array}{c}\text { Dose } \\
{[\mathrm{mg} / \mathrm{kg}]}\end{array}$} & \multirow{2}{*}{$\begin{array}{l}\text { Temp } \\
{\left[\mathrm{t}_{0} \mathrm{~b}\right]^{\circ} \mathrm{C}}\end{array}$} & \multirow{2}{*}{$\begin{array}{l}\text { Temp } \\
{\left[\mathrm{t}_{0} \mathrm{a}\right]^{\circ} \mathrm{C}}\end{array}$} & \multicolumn{5}{|c|}{ Rectal temperature ${ }^{\circ} \mathrm{C}$ in mean $\pm \mathrm{SEM}$} \\
\hline & & & & & $1 \mathrm{hrs.}$ & 2 hrs. & 3 hrs. & $4 \mathrm{hrs}$. & 5 hrs. \\
\hline । & Control & --- & $37.26 \pm 0.1$ & $38.3 \pm 0.1$ & $38.47 \pm 0.1$ & $38.35 \pm 0.2$ & $38.28 \pm 0.1$ & $38.31 \pm 0.1$ & $38.27 \pm 0.1$ \\
\hline$\|$ & Std & 250 & $37.21 \pm 0.1$ & $38.1 \pm 0.3$ & $37.41 \pm 0.3^{*}$ & $36.92 \pm 0.2^{* * *}$ & $36.61 \pm 0.1^{* * *}$ & $36.21 \pm 0.2^{* * *}$ & $35.89 \pm 0.1^{* * *}$ \\
\hline III & AELS & 100 & $37.26 \pm 0.1$ & $38.2 \pm 0.2$ & $38.36 \pm 0.11^{*}$ & $38.11 \pm 0.1^{*}$ & $38.0 \pm 0.13^{*}$ & $37.95 \pm 0.12^{*}$ & $37.56 \pm 0.1^{*}$ \\
\hline IV & AELS & 200 & $37.31 \pm 0.3$ & $38.4 \pm 0.1$ & $38.14 \pm 0.10^{* *}$ & $37.85 \pm 0.13^{* *}$ & $37.67 \pm 0.13^{* *}$ & $37.23 \pm 0.11^{* *}$ & $36.98 \pm 0.15^{* *}$ \\
\hline V & AELS & 400 & $37.29 \pm 0.1$ & $38.4 \pm 0.1$ & $37.93 \pm 0.09 * *$ & $37.47 \pm 0.08^{* * *}$ & $36.92 \pm 0.10^{* *}$ & $36.43 \pm 0.11^{* * *}$ & $36.38 \pm 0.09^{* * *}$ \\
\hline $\mathrm{Vl}$ & AEAR & 100 & $37.34 \pm 0.2$ & $38.3 \pm 0.3$ & $37.65 \pm 0.10$ & $37.63 \pm 0.13$ & $37.55 \pm 0.12$ & $37.57 \pm 0.10$ & $37.5 \pm 0.11$ \\
\hline VII & AEAR & 200 & $37.42 \pm 0.1$ & $38.0 \pm 0.1$ & $37.84 \pm 0.11^{*}$ & $37.69 \pm 0.10^{*}$ & $37.58 \pm 0.14^{*}$ & $37.41 \pm 0.20^{*}$ & $37.23 \pm 0.18^{*}$ \\
\hline VIII & AEAR & 400 & $37.27 \pm 0.1$ & $37.5 \pm 0.1$ & $37.57 \pm 0.17^{* *}$ & $37.65 \pm 0.15^{* *}$ & $37.32 \pm 0.13^{* *}$ & $36.86 \pm 0.11^{* *}$ & $36.61 \pm 0.18^{* *}$ \\
\hline
\end{tabular}

Results are expressed as mean \pm S.E.M. $\mathrm{t}_{0} \mathrm{~b}=$ initial body temperature prior to injection of Brewer $\mathrm{s}$ yeast, $\mathrm{t}_{0} \mathrm{a}=$ body temperature $18 \mathrm{~h}$ after injection of brewer $\mathrm{s}$ yeast, $\mathrm{n}=6$ each group, ${ }^{*} \mathrm{P}<0.05,{ }^{*} \mathrm{P}<0.01,{ }^{* * *} \mathrm{P}<0.001$, significantly different value while compared to the control groups, (ANOVA followed by Dunnet's $\mathrm{t}$-test).

yields a dose dependent decrease in rectal temperature at various time intervals.

\section{Analgesic effect}

\section{Tail immersion test}

Table 2 shows the results of the tail immersion test. At a dose of $400 \mathrm{mg} / \mathrm{kg}$ body weight, AELS $\left({ }^{* * * *} \mathrm{P}<0.001\right)$ and AEAR (** $\mathrm{P}<0.01)$ shows significant reaction time of $6.93 \mathrm{sec}$ and $6.54 \mathrm{sec}$ respectively at $30 \mathrm{~min}$ after extract administration while standard pentazocine showed significant reaction time of $7.62 \mathrm{sec}$. In this model, Figure 2 displays that reaction time increased significantly for the test and standard when compared to the control. The test drugs yield a dose dependent increase in reaction time at various time intervals.

\section{Acetic acid induced writhing test}

Table 3 demonstrate the results of analgesic effect by acetic acid induced writhing method. At a dose of $400 \mathrm{mg} / \mathrm{kg}$ body weight, AELS shows most significant ( $\left.{ }^{* * *} \mathrm{P}<0.001\right)$ inhibition of $63.1 \%$ while AEAR shows inhibition $(* * \mathrm{P}<0.01)$ of $57.1 \%$. On the other hand, At a dose of $200 \mathrm{mg} / \mathrm{kg}$ body weight, AELS and AEAR shows inhibition of $55.36 \%$ $(\mathrm{P}<0.01)$ and $47.86 \%(\mathrm{P}<0.05)$ respectively. Again at a dose of $100 \mathrm{mg} / \mathrm{kg}$ body weight, AELS and AEAR shows inhibition of $48.05 \%$ and $40.76 \%$ respectively $(* \mathrm{P}<0.05)$ while at $50 \mathrm{mg} / \mathrm{kg}$ of standard drug showed $(* * * \mathrm{P}<0.001)$ inhibition of $69.23 \%$. Figure 3 shows the percent inhibition of standard, AELS and AEAR.

\section{Anti-inflammatory effect \\ Carrageenan induced hind paw edema model}

The effect of AELS and AEAR on carrageenan induced hind paw edema method in rats shown in Table 4. The results obtained indicates that, $400 \mathrm{mg} / \mathrm{kg}$ of AELS at $3^{\text {rd }}$ hours showed maximum inhibition $\left({ }^{* * * *} \mathrm{P}<0.001\right)$ of $32.48 \%$ while AEAR showed $(* * \mathrm{P}<0.01)$ inhibition of $26.75 \%$. Again at the dose of $200 \mathrm{mg} / \mathrm{kg}$, AELS and AEAR showed inhibition of $27.39 \%(\mathrm{P}<0.01)$ and $22.93 \%(\mathrm{P}<0.05)$ respectively while Standard indomethacin inhibited $40.13 \%$ of inflammation $\left({ }^{* * * *} \mathrm{P}<0.001\right)$ at the same time. Figure 4

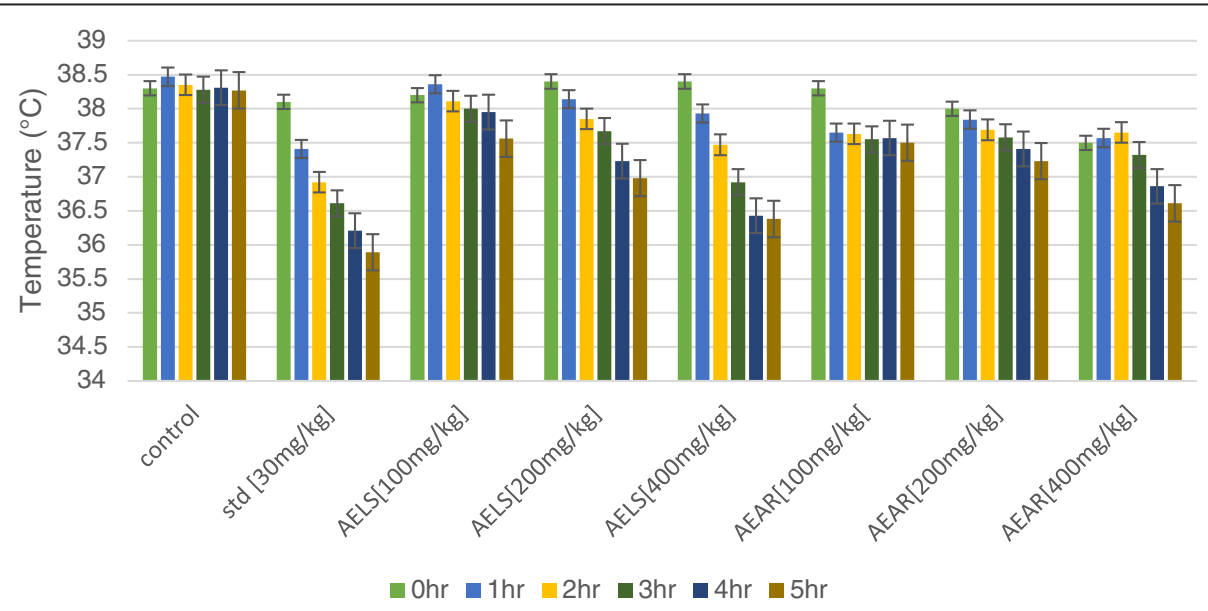

Figure 1 Inhibition of pyrexia of AELS, AEAR and STD. 
Table 2 Effects of AELS, AEAR and pentazocine on tail-immersion test

\begin{tabular}{|c|c|c|c|c|c|c|}
\hline \multirow[t]{2}{*}{ Group } & \multirow[t]{2}{*}{ Treatment } & \multirow{2}{*}{$\begin{array}{c}\text { Dose } \\
{[\mathrm{mg} / \mathrm{kg}]}\end{array}$} & \multicolumn{4}{|c|}{ Average tail withdrawing time $(\mathrm{sec})($ Mean \pm S.E.M) } \\
\hline & & & $0 \mathrm{~min}$ & $15 \mathrm{~min}$ & $30 \mathrm{~min}$ & $60 \mathrm{~min}$ \\
\hline I & Control & --- & $2.62 \pm 0.05$ & $2.87 \pm 0.07$ & $2.61 \pm 0.11$ & $2.49 \pm 0.018$ \\
\hline$\|$ & Standard & 30 & $2.36 \pm 0.06^{* *}$ & $5.81 \pm 0.04^{* * *}$ & $7.62 \pm 0.06^{* * *}$ & $4.38 \pm 0.05^{* * *}$ \\
\hline III & AELS & 100 & $2.66 \pm 0.02^{*}$ & $3.44 \pm 0.05^{*}$ & $5.13 \pm 0.03^{*}$ & $2.98 \pm 0.03^{*}$ \\
\hline IV & AELS & 200 & $2.5 \pm 0.01^{* *}$ & $3.83 \pm 0.05^{* *}$ & $5.9 \pm 0.04^{* *}$ & $3.21 \pm 0.04^{* *}$ \\
\hline V & AELS & 400 & $3.12 \pm 0.02^{* *}$ & $4.86 \pm 0.01^{* * *}$ & $6.93 \pm 0.05^{* * *}$ & $4.24 \pm 0.03^{* * *}$ \\
\hline $\mathrm{Vl}$ & AEAR & 100 & $2.71 \pm 0.05$ & $3.13 \pm 0.04$ & $4.03 \pm 0.05$ & $3.15 \pm 0.08$ \\
\hline VII & AEAR & 200 & $2.33 \pm 0.02^{*}$ & $3.41 \pm 0.03^{*}$ & $4.1 \pm 0.07^{*}$ & $2.85 \pm 0.01^{*}$ \\
\hline VIII & AEAR & 400 & $2.67 \pm 0.01^{* *}$ & $3.84 \pm 0.04^{* *}$ & $6.54 \pm 0.07^{* *}$ & $3.74 \pm 0.03^{* *}$ \\
\hline
\end{tabular}

Values are expressed as mean \pm S.E.M $(n=6)$. ${ }^{*} P<0.05$ (significant), ${ }^{* *} P<0.01$ (more significant) and ${ }^{* * *} P<0.001$ (most significant) compared with vehicle control (ANOVA followed by Dunnet's t-test).

shows the percent of inhibition of inflammation for the test and standard drug. The test drugs yield a dose dependent increase of inhibition at various time intervals.

\section{Cotton-pellet granuloma test}

Table 5 shows the results of anti-inflammatory effect of cotton-pellet granuloma method. At a dose of $400 \mathrm{mg} / \mathrm{kg}$ and $200 \mathrm{mg} / \mathrm{kg}$ body weight, AELS showed most significant $\left({ }^{* * *} \mathrm{P}<0.001\right)$ and significant $\left({ }^{* * *} \mathrm{P}<0.01\right)$ value respectively i.e. inhibition of $34.7 \%$ and $26.72 \%$. On the other hand, at a dose of $400 \mathrm{mg} / \mathrm{kg}$ and $200 \mathrm{mg} / \mathrm{kg}$ body weight, AEAR showed 29.1\% $(\mathrm{P}<0.01)$ and $19.43 \%$ $(\mathrm{P}<0.05)$ inhibition respectively while at $40 \mathrm{mg} / \mathrm{kg}$ of standard drug showed $(* * \%) \mathrm{P}<0.001)$ inhibition of $63.22 \%$. To confer the anti-inflammatory activity, Figure 5 shows the relation in the percent inhibition of inflammation of AENH, AESM and AEAN in both Carrageenan induced (at $3^{\text {rd }}$ hour) and Cotton-pellet granuloma test model.

\section{Discussion}

Our present study was to evaluate the pharmacological effect of methanol extract of Launaea sarmentosa and
Aegialitis rotundifolia roxb on animals while the acute toxicity study exposes that this plant might be considered as a broad nontoxic one. Results regarding various method showed that these plant possess a significant inhibition and reduction of pain, inflammation and pyrexia with a reasonable safety profile.

Pain and pyrexia is generally induced by tissue damage, infections, inflammation, malignancy and other diseasestates or condition, thereby initiates the enhanced formation of pro-inflammatory mediators which boost body temperature [20,21]. Drugs or compounds having antipyretic activity usually show an inhibitory effect on cyclooxygenase- 2 expression, thus inhibiting biosynthesis of PGE2 and consequently decreases the elevated body temperature [40]. Yeast-induced fever or pyrexia is also called pathogenic fever and its etiology could be the production of prostaglandins which set the thermoregulatory center to increase body temperature [41]. Yeastinduced pyrexia is considered as a useful test for the screening of synthetic drugs as well as plant extracts for their antipyretic activity [41,42]. These agents or compounds acts to suppress the peripheral formation of pyrogenic cytokines while blocking the COX pathways and

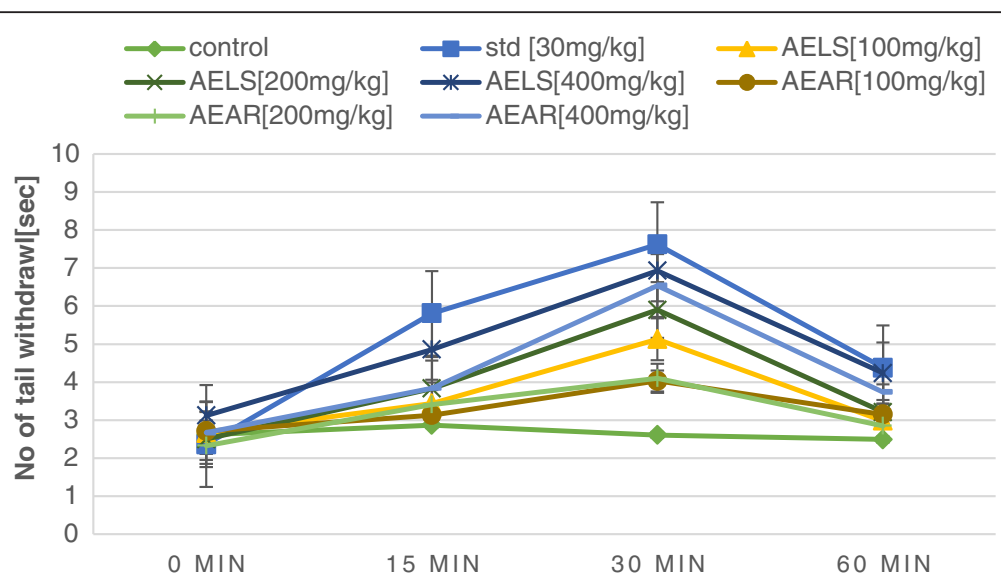

Figure 2 Reaction time for tail immersion test of AELS, AEAR and STD. 
Table 3 Effects of AELS, AEAR and aspirin on acetic acid induced writhing method

\begin{tabular}{ccccc}
\hline Group & Treatment & $\begin{array}{c}\text { Dose } \\
{[\mathbf{m g} / \mathbf{k g}]}\end{array}$ & $\begin{array}{c}\text { No. of writhes [15 min] } \\
\text { (Mean } \pm \text { S.E.M) }\end{array}$ & $\begin{array}{c}\text { Inhibition } \\
\text { (\%) }\end{array}$ \\
\hline I & Control & --- & $48.33 \pm 1.13$ & -- \\
II & Standard & 50 & $14.87 \pm 0.09^{* * *}$ & $69.23 \%$ \\
III & AELS & 100 & $25.1 \pm 0.12^{*}$ & $48.05 \%$ \\
IV & AELS & 200 & $21.57 \pm 0.11^{* *}$ & $55.36 \%$ \\
V & AELS & 400 & $17.83 \pm 0.1^{* * *}$ & $63.10 \%$ \\
VI & AEAR & 100 & $28.63 \pm 0.14$ & $40.76 \%$ \\
VII & AEAR & 200 & $25.20 \pm 0.13^{*}$ & $47.86 \%$ \\
VIII & AEAR & 400 & $20.73 \pm 0.10^{* *}$ & $57.10 \%$ \\
\hline
\end{tabular}

Values are expressed as mean \pm S.E.M $(n=6) .{ }^{*} P<0.05$ (significant), ${ }^{* *} P<0.01$ (more significant) and ${ }^{* * *} \mathrm{P}<0.001$ (most significant) compared with vehicle control (ANOVA followed by Dunnet's t-test).

lowering the thermoregulatory set point. In our present study, the intraperitoneal administration of L. sarmentosa in yeast induced fevered rat shows significant attenuated rectal temperature while $A$. rotundifolia roxb show moderate significant activity and their effect are comparable to that of standard anti-pyretic drug, aspirin. It is inferred that such activity of the extract may be due to the presence of active non-steroidal compounds, single bioactive substance or a mixture of compounds and inhibition of prostaglandin biosynthesis could be the possible mechanism of action of such antipyretic activity. Also, there are several other mediators or multi-processes introducing the pathogenesis of fever and inhibition of any of these responsible mediators may bring such anti-pyresis [43]. Flavonoids are common polar compounds that have previously reported in our plant extract $[29,31]$ which are generally known to have such anti-pyretic activity $[44,45]$.

Acetic acid induced writhing method is generally used to determine peripherally acting analgesic action and represents pain sensation which acts by triggering localized inflammatory reaction. This method is not only simple, reliable, sensitive but also affords rapid evaluation of peripheral analgesic action [46]. In our study, intraperitoneal administration of noxious chemical acetic acid causes the twisting of dorsoabdominal muscles constrictions because of irritation of peritoneal cavity in which acetic acid is thought to discharge of prostaglandins E2 and F2 $\alpha$ mediators as well as lipoxygenase mediators that excite pain nerve endings by inflammatory response [47]. These endogenous mediators of inflammatory pain are sensitive to nonsteroidal anti-inflammatory drugs (NSAID) and opioids [48]. It is well known that non-steroidal anti-inflammatory and analgesic drugs play role in diminishing the inflammatory pain at the peripheral target sites by inhibiting or blocking the formation of pain mediators whereas bradykinin and prostaglandins are responsible for pain process [49]. In the present study, the analgesic action of $L$. sarmentosa and $A$. rotundifolia roxb can be attributed to the significant reduction of writhes in mice, suggests that the analgesic effect may be mediated peripherally via the inhibition of release and synthesis of PGs and other endogenous mediators. It also suggests that $L$. sarmentosa has superior inhibitory action than $A$. rotundifolia roxb in the inhibition of COX pathway which is actually involved in prostaglandin biosynthesis.

Although acetic acid induced writhing method in animals is a very sensitive but not a selective pain test. Thus to corroborate that the plant has analgesic activity, tail immersion tests were also directed which signify the centrally acting analgesic activity. Tail immersion test is well-thought to spinal response or reflexes, but could also involve higher neural structures which mainly confers central analgesic action [50] and is also highly correlated with relief of human pain perception [51]. From the results of above two methods, it can be inferred that $L$. sarmentosa showed central and peripheral analgesic action in both tail immersion and acetic acid writhing method which is more significant than $A$. rotundifolia roxb. Preliminary phytochemical studies of $L$. sarmentosa revealed the presence of terpenoid, tannin, glycoside, alkaloid $[29,31]$ which are generally known to involve in the inhibition of synthesis of prostaglandins, leukotriene's, and other endogenous substances that are key players in triggering pain perception $[44,52,53]$.

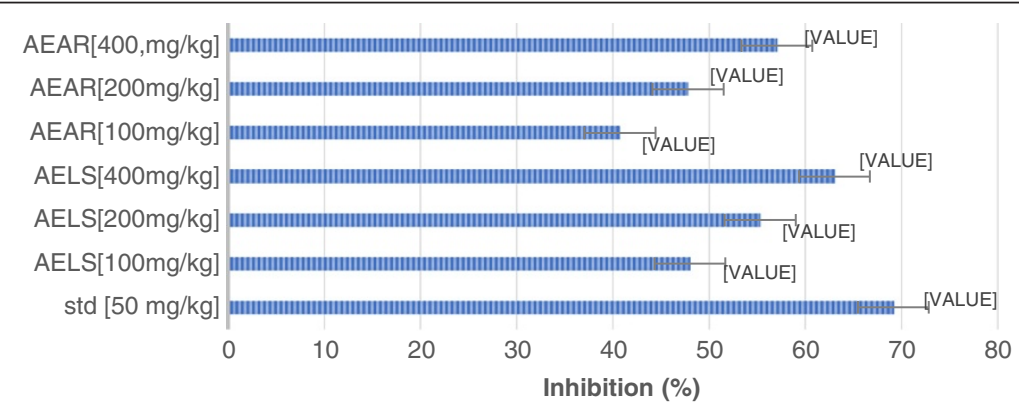

Figure 3 Percent Inhibition of pain of AELS, AEAR and STD. 
Table 4 Effects of AELS, AEAR and Standard drug on carrageenan induced inflammation on rats

\begin{tabular}{|c|c|c|c|c|c|c|c|c|c|}
\hline \multirow[t]{2}{*}{ Group } & \multirow[t]{2}{*}{ Treatment } & \multirow{2}{*}{$\begin{array}{c}\text { Dose } \\
{[\mathrm{mg} / \mathrm{kg}]}\end{array}$} & \multicolumn{4}{|c|}{ Paw volume at different time interval (in $\mathrm{ml}$ ) (Mean \pm S.E.M) } & \multicolumn{3}{|c|}{ Inhibition (\%) } \\
\hline & & & 0 hour & 1 hour & 2 hour & 3 hour & 1 hour & 2 hour & 3 hour \\
\hline I & Control & --- & $.77 \pm .048$ & $1.07 \pm .059$ & $1.27 \pm .052$ & $1.57 \pm .011$ & --- & --- & --- \\
\hline$\|$ & Standard & 10 & $.61 \pm .003$ & $.73 \pm .02^{* *}$ & $.86 \pm .03^{* * *}$ & $0.94 \pm .02^{* * *}$ & 31.8 & 32.3 & 40.13 \\
\hline III & AELS & 100 & $.72 \pm .04$ & $.95 \pm .05^{*}$ & $1.11 \pm .05^{*}$ & $1.21 \pm .04^{*}$ & 11.21 & 12.59 & 22.93 \\
\hline IV & AELS & 200 & $.67 \pm .03$ & $.91 \pm .03^{* *}$ & $1.06 \pm .06^{* *}$ & $1.14 \pm .005^{* *}$ & 15 & 16.5 & 27.39 \\
\hline V & AELS & 400 & $.73 \pm .03$ & $.87 \pm .04^{* *}$ & $.98 \pm .04^{* * *}$ & $1.06 \pm .05^{* * *}$ & 18.7 & 22.8 & 32.48 \\
\hline $\mathrm{Vl}$ & AEAR & 100 & $0.74 \pm 0.02$ & $0.98 \pm .02$ & $1.14 \pm .03$ & $1.31 \pm .05$ & 8.41 & 10.23 & 16.56 \\
\hline VII & AEAR & 200 & $.69 \pm .03$ & $.93 \pm .05^{*}$ & $1.1 \pm .06^{*}$ & $1.21 \pm .04^{*}$ & 13.0 & 13.39 & 22.93 \\
\hline VIII & AEAR & 400 & $.64 \pm .03$ & $.91 \pm .03^{* *}$ & $1.06 \pm .06^{* *}$ & $1.15 \pm .06^{* *}$ & 15.0 & 16.5 & 26.75 \\
\hline
\end{tabular}

Values are expressed as mean \pm S.E.M $(n=6) . * P<0.05$ (significant), ${ }^{* * P}<0.01$ (more significant) and ${ }^{* * *}<0.001$ (most significant), compared with vehicle control (ANOVA followed by Dunnet's t-test).

Pain and inflammation are pathophysiologically related with various clinical situations such as cancer, arthritis and vascular diseases. The testing of inflammation by carrageenan-induced is designated because of its selectivity in identifying orally active inflammatory agents, particularly in the severe phase of inflammation [54]. It is treated as a significant predictive method for the screening of anti-inflammatory agents which acts to inhibit the mediators of acute inflammation $[55,56]$. The carrageenaninduced paw edema in rat is a biphasic process. The histamine or serotonin is released in the first phase and the bradykinin, prostaglandin, protease, and lysosome is produced in second phase [57]. Based on these reports and obtained results, it is concluded that the methanolic extract of $L$. sarmentosa and A. rotundifolia roxb exhibited significant suppression of paw edema formation in rats that was measured in the third hour of experimentation and that perhaps acts by inhibiting the release and/or local actions of vasoactive substances. It is suggested based on the facts that the late phase of carrageenan-induced edema is accompanying with the release of prostaglandin-like mediators and is clinically sensitive to steroidal and nonsteroidal (NSAID) anti-inflammatory agents.

On the other hand, chronic inflammation develop when the body response is insufficient to eliminate the proinflammatory agents. Thus proliferation of fibroblasts and the infiltration of cells, neutrophils and exudation $[58,59]$ occurs which by means of the early development of proliferative cells. These developed cells can either be in spread or granuloma form [59]. The cotton pellet-induced granuloma model is widely used to assess the proliferative components of chronic inflammation in where a subcutaneously imbedded cotton pellet in the rats show a transudate phase, an exudative phase and a proliferative phase of the inflammatory response [60]. Reduction in dry pellet weight could result due to decrease production of fibroblasts and synthesis of collagen and mucopolysaccharides during formation of granuloma tissue and thus signifies the suppression of inflammatory proliferative phase [61]. In the present study, administration of L. sarmentosa $(400 \mathrm{mg} / \mathrm{kg}$, p.o.) was found to reduce the weight of cotton pellet in a dose dependent manner and significantly reduced the granuloma tissue formation by higher doses of the extract which is close to the inhibitory effect of standard indomethacin and is better than the effect of A. rotundifolia roxb.

This investigation suggest that smaller doses are less effective in reducing migration of leucocytes into the areas of inflammation, since it is known that granuloma formation is due to leukocyte accumulation [62]. Flavonoids and terpenoids are compounds effective in treating acute inflammation whereas steroids and glycosides are the constituents

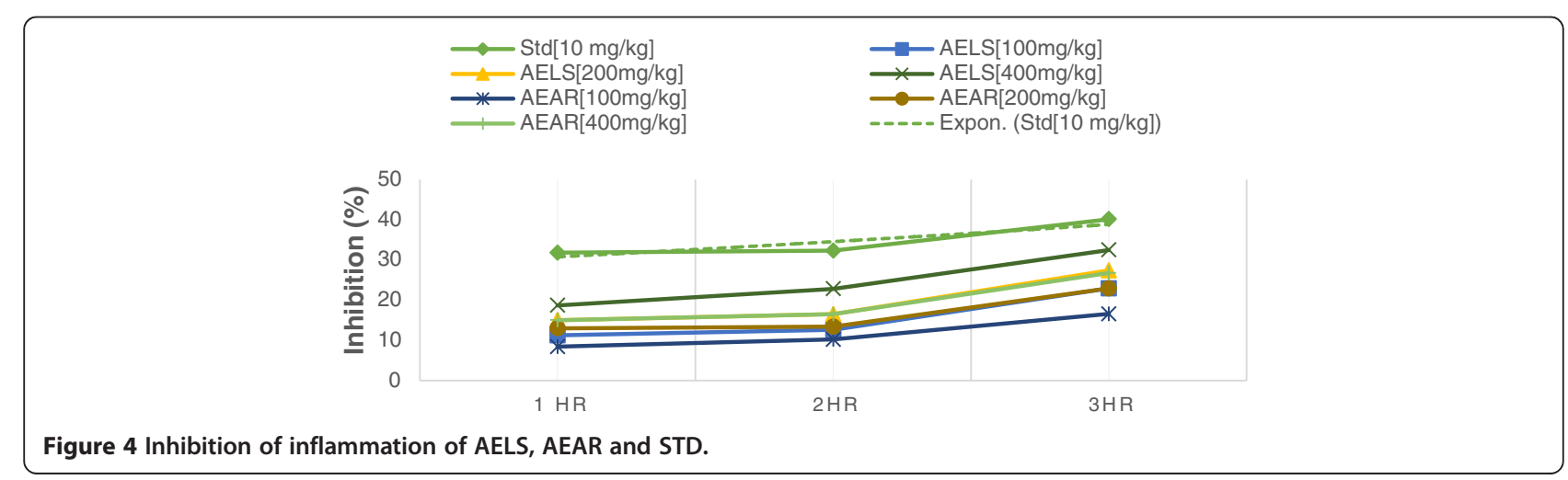


Table 5 Anti-inflammatory activity of AELS, AEAR and Standard drug on Cotton-pellet granuloma induced inflammation on rats

\begin{tabular}{ccccc}
\hline Group & Treatment & $\begin{array}{c}\text { Dose } \\
\text { [mg/kg] }\end{array}$ & $\begin{array}{c}\text { Weight of dry cotton } \\
\text { pellet granuloma }(\mathbf{m g})\end{array}$ & Inhibition (\%) \\
\hline I & Control & --- & $41.12 \pm 0.32$ & --- \\
II & Standard & 40 & $15.12 \pm 0.09^{* * *}$ & 63.22 \\
III & AELS & 100 & $33.56 \pm 0.21^{*}$ & 18.38 \\
IV & AELS & 200 & $30.13 \pm 0.20^{* *}$ & 26.72 \\
V & AELS & 400 & $26.85 \pm 0.17^{* * *}$ & 34.7 \\
VI & AEAR & 100 & $35.26 \pm 0.19$ & 14.25 \\
VII & AEAR & 200 & $33.13 \pm 0.20^{*}$ & 19.43 \\
VIII & AEAR & 400 & $29.15 \pm 0.18^{* *}$ & 29.1 \\
\hline
\end{tabular}

Values are expressed as mean \pm S.E. $(n=6) .{ }^{*} P<0.05,{ }^{* * P}<0.01$ and ${ }^{* * * P}<0.001$ compared with vehicle control (ANOVA followed by Dunnet's t-test).

that are effective in chronic inflammation [63]. These phytocompounds are well recognized for anti-inflammatory possessions as well as inhibition of pain perception which have previously reported in the extract of $L$. sarmentosa $[29,31]$. Flavonoids are well known compound for the analgesic, anti-inflammatory and antipyretic activities [44,45]. So it is anticipated that the present studies will stimulate further efforts towards the development of new, safe, more effective and urgently needed medications with lesser side effects for the treatment of fever, pain and inflammatory diseases.

\section{Conclusions}

On the basis of these findings, it may be inferred that methanolic extract of $L$. sarmentosa and A. rotundifolia roxb has moderate analgesic, anti-pyretic and anti-inflammatory activities. It also found that, these activities were related to the dose and these results corroborate the traditional and local use of these plant in folk medicine. At present, there are no extensive reports on investigation to identify the main active phytochemical components present in methanolic extract of $L$. sarmentosa and A. rotundifolia roxb. Further investigations are anticipated to identify those active components present, in order to development of a potent and safe analgesic, anti-inflammatory and antipyretic drug.

\section{Methods}

\section{Plant material}

The bark, stem and leaves of $L$. sarmentosa and $A$. rotundifolia roxb were collected from the Sonadia deep of Cox's Bazar. The plant material was originally identified and authenticated by Bangladesh National Herbarium, Mirpur, Dhaka. The voucher specimen numbers were DACB: 38312 and DACB: 38310 for L. sarmentosa and A. rotundifolia roxb respectively.

\section{Preparation of extracts}

The bark, stem and leaves of $L$. sarmentosa and $A$. rotundifolia roxb were washed thrice with speedy running tape water and twice with distilled water to remove the adhered salts, soils and other associated animals, parasites and then dried in shade at temperature between $21-30^{\circ} \mathrm{C}$ for 15 days. After the process of drying, these were grounded in blender into fine powders. Then $450 \mathrm{gm}$ of each fine powdered crude plant was subjected for cold extraction process by macerating with $2100 \mathrm{ml}$ of $98 \%$ methanol at room temperature for a week. At the end of 7 days, each macerate was filtrate with whatman No 1 filter paper and evaporated using a rotatory evaporator (Büchi 011, USA) so as to get semi-solid extract. Residue left at the bottom of the beaker is the crude methanol extract of $L$. sarmentosa and A. rotundifolia roxb. The filtrate finally obtained was air dried and kept in refrigerator maintained at $4^{\circ} \mathrm{C}$ for further test.

\section{Experimental animals}

In the experiment, Swiss Albino Mice (25-30 g) and Wister Albino Rats (180-210 g) of either sex were used.

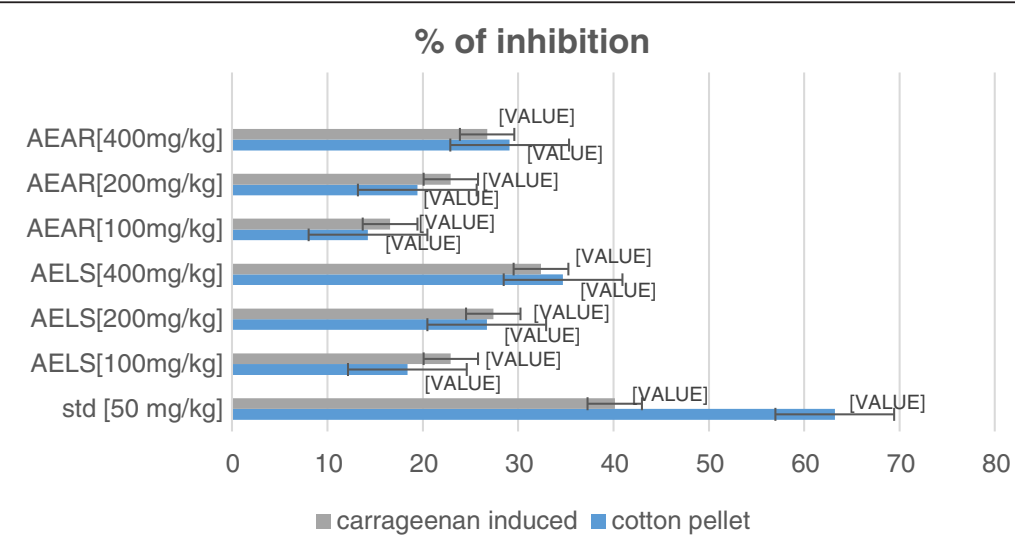

Figure 5 Relation of \% inhibition of inflammation in both carrageenan and cotton pellet model. 
They were collected from Jahangir Nagar University of Dhaka, Bangladesh. Animals of both category were kept in cages of polypropylene and feed on water ad libitum and standard laboratory pellet diet. Animals were uncovered to alternate cycle of $12 \mathrm{~h}$ light and dark while temperature of $25 \pm 2^{\circ} \mathrm{C}$ and relative humidity of $55 \pm 10 \%$ were also maintained. Animals were permitted for 7 days to adapt to the laboratory conditions before the start of experiment. This present project work was cleared by the Institutional Animal Ethical Committee [IAEC].

\section{Acute toxicity studies}

According to the procedures set by organization for economic co-operation and development guidelines (OECD), acute toxicity studies were accomplished for the plant extracts of AELS and AEAR [64]. Swiss Albino Mice (25-30 g) and Wister Albino Rats (180-210 g) of same age and either sex were taken into account to evaluate the acute toxicity level of proposed plant extract. For the experiment they were fasted whole night and only water ad libitum was allowed. Thus, different groups having six mice in each were orally administered with different prepared aqueous extracts of 100, 200, 400, 800 and $1000 \mathrm{mg} / \mathrm{kg}$ p.o respectively. After dosing, the rate of mortality and common behavior of these groups were witnessed continuously for initial $4 \mathrm{~h}$, and intermittently for $6 \mathrm{~h}$ and then again at $24 \mathrm{~h}$ and $48 \mathrm{~h}$ respectively. In these experiment, doses of $1000 \mathrm{mg} / \mathrm{kg}$ show significant reduction in survival of mice (LD50- around $1000 \mathrm{mg} / \mathrm{kg} / \mathrm{b} . \mathrm{wt}$ ). Hence, 100/200/400 mg/kg/b.wt of AELS and AEAR was considered for the present studies. Common behaviors of these animals such as convulsion, pilo erection, aggressiveness, loss of lighting reflex, analgesia, grooming, skin color, sedation, hypnosis, diarrhea and respiratory rate were also observed after dose administration [65].

\section{Chemicals and drugs}

Carragennan (Sigma Aldrich Inc., St Louis, MO, USA), Brewer's Yeast (Arkopharma, Carros, France), Acetic acid (Merck Germany), Methanol (Merck Germany), Standard Diclofenac sodium, Indomethacin, aspirin, pentazocine and acetyl salicylic acid (Beximco Pharmaceuticals Ltd., Bangladesh). Chemicals used for present work were of analytical grade and arranged in the form of suspensions using a few drops of suspending agent diluted with distilled water.

\section{Methods for the evaluation of anti-pyretic effect Brewer's yeast induced pyrexia method}

This model was run to study the anti-pyretic activity, slightly modifying the method described by Adams et al. [66]. Total 8 groups of six animals each are taken into individual cages. To bring fever, $20 \%$ aqueous suspension of Brewer's yeast $(10 \mathrm{ml} / \mathrm{kg})$ were injected into all group of animal's dorsum region. About $18 \mathrm{~h}$ after the injection of pyretic agent, the rectal temperature was measured individually by a digital thermometer (SK-1250 MC, Sato keiryoki Mfg). Only those animals that shows an increase in temperature of at least $0.6^{\circ} \mathrm{C}$ are certified for the experiment. At 18 hour of brewer's yeast administration, the following doses of sample was directed.

Group I: Treated as control, received vehicle $10 \mathrm{ml} / \mathrm{kg}$ normal saline p.o.

Group II: Received standard drug acetyl salicylic acid (250 mg/kg p.o.) dissolved in distilled water

Group III: Received AELS 100 mg/kg p.o. suspended in $2 \% \mathrm{w} / \mathrm{v}$ gum acacia solution.

Group IV: Received AELS 200 mg/kg p.o. suspended in $2 \% \mathrm{w} / \mathrm{v}$ gum acacia solution.

Group V: Received AELS $400 \mathrm{mg} / \mathrm{kg}$ p.o. suspended in $2 \% \mathrm{w} / \mathrm{v}$ gum acacia solution

Group VI: Received AEAR 100 mg/kg p.o. suspended

in $2 \% \mathrm{w} / \mathrm{v}$ gum acacia solution.

Group VII: Received AEAR 200 mg/kg p.o. suspended in $2 \% \mathrm{w} / \mathrm{v}$ gum acacia solution.

Group VIII: Received AEAR 400 mg/kg p.o. suspended in $2 \% \mathrm{w} / \mathrm{v}$ gum acacia solution.

After sample and drug administration, rectal temperature of each rate was recorded by a digital thermometer at 0,1 , 2 and $3 \mathrm{hr}$. Thus average rectal temperature of each group $(n=6)$ was calculated and compared with standard drug acetyl salicylic acid.

\section{Methods for the evaluation of analgesic effect Tail immersion method}

In the present study, analgesia was evaluated following Luiz et al. method [67]. Total 8 groups of six animals each are taken into individual cages and the animals were allowed to adopt in the cage environment for half an hour before the start of experiment. All animals were held in position with the tail extending out in a suitable restrainer. Freshly filled hot water maintained at $55.0 \pm 1.0^{\circ} \mathrm{C}$ were used to immerse the lower $5 \mathrm{~cm}$ portion of the tail and the time to withdrawal of the tail was noted as the reaction time or tail flick latency. Any animals fail to withdraw its tail from hot water within $10 \mathrm{sec}$ is rejected from the experiment.

Group I: Control group animals received $10 \mathrm{ml} / \mathrm{kg}$ of $0.5 \%$ sodium lauryl sulphate (SLS). Group II: animals received Standard drug Pentazocine at dose of $30 \mathrm{mg} / \mathrm{kg}$ i.p.

Group III: Received AELS $100 \mathrm{mg} / \mathrm{kg}$ in $0.5 \%$ SLS p.o. Group IV: Received AELS $200 \mathrm{mg} / \mathrm{kg}$ in $0.5 \%$ SLS p.o. Group V: Received AELS $400 \mathrm{mg} / \mathrm{kg}$ in $0.5 \%$ SLS p.o. Group VI: Received AEAR $100 \mathrm{mg} / \mathrm{kg}$ in 0.5\% SLS p.o. Group VII: Received AEAR $200 \mathrm{mg} / \mathrm{kg}$ in 0.5\% SLS p.o. 
Group VIII: Received AEAR $400 \mathrm{mg} / \mathrm{kg}$ in $0.5 \%$ SLS p.o.

After administration of above scheduled dose, the reaction time was counted at $0,15,30$ and 60 min respectively. The mean reaction time for each group was recorded and compared with the value of standard [68].

\section{Acetic acid induced writhing method}

Peripheral analgesic activity is widely assessed by using acetic acid induced writhing technique in which acetic acid solution was intraperitoneally injected and the number of stretching's and writhings was counted as previously reported by Koster et al. and Hendershot \& Forsaith et al. $[69,70]$. Total 8 groups of six animals each are employed into individual cages.

Group I: Control group animals received $10 \mathrm{ml} / \mathrm{kg}$ of $2 \%$ tween.

Group II: Standard group animals received Aspirin at dose of $50 \mathrm{mg} / \mathrm{kg}$ i.p.

Group III: Received AELS $100 \mathrm{mg} / \mathrm{kg}$ in $2 \%$ tween p.o. Group IV: Received AELS $200 \mathrm{mg} / \mathrm{kg}$ in $2 \%$ tween p.o. Group V: Received AELS $400 \mathrm{mg} / \mathrm{kg}$ in 2\% tween p.o. Group VI: Received AEAR $100 \mathrm{mg} / \mathrm{kg}$ in 2\% tween p.o. Group VII: Received AEAR $200 \mathrm{mg} / \mathrm{kg}$ in $2 \%$ tween p.o. Group VIII: Received AEAR $400 \mathrm{mg} / \mathrm{kg}$ in 2\% tween p.o.

All the scheduled test doses were administered orally $1 \mathrm{hr}$ prior to injection of acetic acid intraperitonealy $(0.1 \mathrm{ml}$ of $0.6 \% \mathrm{v} / \mathrm{v})$. After the five minutes of acetic acid injection, the number of writhing movements was recorded for individual animals for a period of $15 \mathrm{~min}$ which was considered as withering of the abdominal muscles of animal accompanied by stretching with a jerk at the hind limb. The counted number of writhing in each treated animal group was then compared to that of a control group.

$$
\begin{array}{r}
\text { \% inhibition formula }=[(\mathrm{C}-\mathrm{T}) / \mathrm{C}] \times 100 \% \\
\text { Where, } \mathrm{C}=\text { Mean of control } \\
\mathrm{T}=\text { Mean of treated }
\end{array}
$$

\section{Methods for the evaluation of anti-inflammatory effect Carrageenan induced hind paw edema model}

Anti-inflammatory activity was evaluated in accordance of slightly revising the method described by Winter et al. [55]. Total 8 groups of six animals each are placed into individual cages.

Group I: Control group animals received $10 \mathrm{ml} / \mathrm{kg}$ of $1 \%$ propylene glycol.

Group II: Animals received standard Indomethacin at dose of $8 \mathrm{mg} / \mathrm{kg}$ i.p.
Group III: Received AELS $100 \mathrm{mg} / \mathrm{kg}$ in $1 \%$ propylene glycol p.o.

Group IV: Received AELS $200 \mathrm{mg} / \mathrm{kg}$ in 1\% propylene glycol p.o.

Group V: Received AELS $400 \mathrm{mg} / \mathrm{kg}$ in 1\% propylene glycol p.o.

Group VI: Received AEAR $100 \mathrm{mg} / \mathrm{kg}$ in 1\% propylene glycol p.o.

Group VII: Received AEAR $200 \mathrm{mg} / \mathrm{kg}$ in 1\% propylene glycol p.o.

Group VIII: Received AEAR $400 \mathrm{mg} / \mathrm{kg}$ in 1\% propylene glycol p.o.

After $1 \mathrm{~h}$ of above drug treatment, 2\% w/v Carrageenan solution $(0.05 \mathrm{ml})$ were injected subcutaneously into sub plantar tissue of right hind paw of each animal and the contra lateral hind paws of same animal were also injected with $0.1 \mathrm{ml}$ of saline as control. The increased paw volume was then plethysmographically measured at $0,1,2$ and $3 \mathrm{~h}$ after injection of odematogenic agent. Actual edema volume was calculated from the difference between initial and subsequent reading and the percent inhibition activity was calculated by using the formula-

$\%$ Inhibition $=\frac{\text { Mean paw inflammation of control }- \text { Mean paw inflammation of test }}{\text { Mean paw inflammation of control }} \times 100$

\section{Cotton-pellet granuloma model}

Cotton pellet induced granuloma model in rats are used to produce sub-acute inflammation [71,72]. Total 8 groups of six animals each are placed into individual cages. Sterilized dental cotton rolls (Johnson and Johnson, New Brunswick, NJ, USA) were cut into 5-mm pieces and two sterilized cotton pellets weighing $10 \pm 1 \mathrm{mg}$ were subcutaneously implanted along the flanks of axillae and groins bilaterally under ether anesthesia.

Group I: Control group animals received $10 \mathrm{ml} / \mathrm{kg}$ of $1 \%$ propylene glycol.

Group II: Animals received Standard Diclofenac sodium at dose of $40 \mathrm{mg} / \mathrm{kg}$ p.o.

Group III: Received AELS $100 \mathrm{mg} / \mathrm{kg}$ in 1\% propylene glycol p.o.

Group IV: Received AELS $200 \mathrm{mg} / \mathrm{kg}$ in 1\% propylene glycol p.o.

Group V: Received AELS $400 \mathrm{mg} / \mathrm{kg}$ in 1\% propylene glycol p.o.

Group VI: Received AEAR $100 \mathrm{mg} / \mathrm{kg}$ in 1\% propylene glycol p.o.

Group VII: Received AEAR $200 \mathrm{mg} / \mathrm{kg}$ in 1\% propylene glycol p.o.

Group VIII: Received AEAR $400 \mathrm{mg} / \mathrm{kg}$ in 1\% propylene glycol p.o. 
Following drugs were administered orally for 6 consecutive days. On the $7^{\text {th }}$ day, the animals were sacrificed by cervical dislocation and the collected granulomas were dried in an oven for $24 \mathrm{hr}$ at $60^{\circ} \mathrm{C}$, then weighed and compared with control.

\section{Statistical analysis}

All of values were expressed as mean \pm SEM. Each results were analyzed for statistical significance using one-way ANOVA followed by Dunnet's' $t$ ' test with ${ }^{*} \mathrm{P}<0.05$, ${ }^{* *} \mathrm{P}<$ 0.01 and ${ }^{* * *} \mathrm{P}<0.001$ were considered as significant value.

\section{Abbreviations}

AELS: Aqueous extract of Launaea sarmentosa; AEAR: Aqueous extract of Aegialitis rotundifolia roxb; COX: Cyclooxygenase; LOX: Lipoxygenase; NSAID: Non-steroidal anti-inflammatory drugs.

\section{Competing interests}

The authors declare that they have no competing interests.

\section{Authors' contributions}

MSH- participated in experiments, study design, manuscript preparation. GSR- carried out the study design, participated in experiments, manuscript preparation. MMR-Supervising and directing the project. MMB-checked the grammatical mistakes and corrected the final manuscript. MSH \& MMHparticipated in experiments and statistics analysis. MMH, SKA- assisted to do extraction. SMMR- plant identification, literature search and data collection. All authors read and approved the final version of the manuscript.

\section{Author details}

${ }^{1}$ Department of Pharmacy, Noakhali Science and Technology University, Sonapur, Noakhali 3814, Bangladesh. ${ }^{2}$ Department of Pharmacy, Dhaka International University, Dhaka, Bangladesh.

Received: 8 September 2014 Accepted: 11 October 2014 Published: 28 October 2014

\section{References}

1. Dassoler M, Schwanz M, Busseto F, Moreira EA, Gutierrez L: Perfil fitoquímico e ensaio farmacológico de Averrhoa carambola L. (Oxalidaceae). J Brasileiro Fitomedicina 2004, 2:4-8.

2. O'Byrne KJ, Dalgleish AG: Chronic immune activation and inflammation as the cause of malignancy. Br J Cancer 2001, 85:473-483.

3. O'Byrne KJ, Dalgleish AG, Browning MJ, Steward WP, Harris AL: The relationship between angiogenesis and the immune response in carcinogenesis and the progression of malignant disease.

Eur J Cancer 2000, 36:151-169.

4. Paterson HM, Murphy TJ, Purcell EJ, Shelley O, Kriynovich SJ, Lien E, Mannick JA, Lederer JA: Injury primes the innate immune system for enhanced Toll-like receptor reactivity. J Immuno/ 2003, 171:1473-1483.

5. Saklatvala J, Dean J, Clark A: Control of the expression of inflammatory response genes. Biochem Soc Symp 2003, 70:95-106.

6. Nakamura Y, Kozuka M, Naniwa K, Takabayashi S, Torikai K, Hayashi R, Sato T, Ohigashi H, Osawa T: Arachidonic acid cascade inhibitors modulate phorbols ester-induced oxidative stress in female ICR mouse skin: differential roles of 5-lipoxygenase and cyclooxygenase-2 in leukocyte infiltration and activation. Free Radic Biol Med 2003, 35:997-1007.

7. Okamoto T, Gohil K, Finkelstein El, Bove P, Akaike T, Van Der Vliet A: Multiple contributing roles for NOS2 in LPS-induced acute airway inflammation in mice. Am J Physiol Lung Cell Mol Physiol 2004, 286:L198-L209.

8. Rang HP, Dale MM, Ritter JM: Pharmacology. In Guanabara- Koogan, Rio de Janeiro. 4th edition. 2001:174-188. 691 pp.

9. Funk CD: Prostaglandins and leukotrienes: advances in eicosanoid biology. Science 2001, 294:1871-1875.

10. Chaitanya R, Sandhya S, David B, Vinod KR, Murali S: HRBC membrane stabilizing property of roor, stem and leaf of glochidion velutinum. Int J Res Pharmaceut Biomed Sci 2011, 2(1):256-259.
11. Anosike CA, Onyechi O, Lawrence US Ezeanyika: Membrane stabilization as a mechanism of the anti-inflammatory activity of methanol extract of garden egg (Solanum aethiopicum). DARU J Pharmaceut Sci 2012, 20:76.

12. Mahan LK, Arlin MT: Krause's Food, Nutrition, and Diet Therapy. 8th edition. Philadelphia, Pa: WB Saunders Co; 1992. 147, 390

13. Nutritional Biochemistry and Metabolism. In 2nd edition. Edited by Linder MC. Elsevier; 1991.

14. Kanodia L, Das S: A comparative study of analgesic property of whole plant and fruit extracts of Fragaria vesca in experimental animal models. Bangladesh J Pharmacol 2008, 4:35-38.

15. Michel YB, Dubois Christopher G, Allen HL: Chronic pain management. In Wylie and Churchil-Davidson's A practice of Anaesthesia. 7th edition. Edited by Healy TEJ, Knight PR. London: Hodder Arnold; 2003:1139-1235.

16. Steiner AA, Ivanov Al, Serrats J, Hosokawa H, Phayre AN, Robbins JR, Roberts $J$, Kobayashi S, Matsumura K, Sawchenko PE, Romanovsky AA: Cellular and molecular bases of the initiation of fever. PLOS Biol 2006, 4:e284.

17. Panthong A, Supraditaporn W, Kanjanapothi D, Tae Sotikul T, Reutrakul V: Analgesic, anti - inflammatory and ventonic effects of Cissus quadrangularis Linn. J Ethnopharmacol 2007, 110:264-270.

18. Zakaria ZA, Abdul Gani ZDF: Antinociceptive, anti-inflammatory, and antipyretic properties of an aqueous extract of Dicranopteris linearis leaves in experimental animal models. J Nat Med 2008, 62(2):179-187.

19. Chattopadhyay D, Arunachalam G, Ghosh L: Antipyretic activity of Alstonia macrophylla Wall ex A. DC: An ethnomedicine of Andaman Islands. J Pharm Pharmaceut Sci 2005, 8:558-564.

20. Spacer CB, Breder CD: The neurologic basis of fever. N Engl J Med 1994, 330:1880-1886.

21. Rivest S, Lacroix S, Vallieres L: How the blood talks to the brain parenchyma and the paraven $\neg$ tricular nucleus of the hypothalamus during systemic inflammatory and infectious stimuli. Proc Soc Exp Biol Med 2000, 223:22-38.

22. Cheng L, Ming-liang $H$, Lars B: Is COX-2 a perpetrator or a protector? Selective COX-2 inhibitors remain controversial. Acta Pharmacol Sin 2005, 26:926-933.

23. Thomas MC: Diuretics, ACE inhibitors and NSAIDs - the triple whammy. Med J Aust 2000, 172:184-185.

24. Kayyalap SO: Medicinal pharmacology, in terms of rational treatment (Rasyonel tedavi yonunden tibbi farmakoloji). Ankara: Hacettepe- Tas Ltd Sti; 1998.

25. Yegnanarayan R: Comparison of anti-inflammatory activity of various extracts of Curcuma longa (Linn). Indian J Med 1976, 64:601-608.

26. Arora RB: Anti-inflammatory studies on Curcuma longa (Turmeric). Indian J Med 1971, 59:1289-1295.

27. Kiuchi F, Iwakami S, Shibuya M: Inhibition of prostaglandin and leukotriene biosynthesis by gingerols and diarylheptanoids. Chem Pharm Bull 1992, 40:387-391.

28. Ammon HPT, Safayhi H, Mack T: Mechanism of anti-inflammatory actions of curcumine and boswellic acids. J Ethnopharmacol 1993, 38:113-119.

29. Yusriyya S, Harisha CR, Vinay J, Shukla and Rabinarayan Acharya: Pharmacognostical evaluation of Launaea sarmentosa (Willd.) schultz-bip.ex Kuntze root. J Res Ayurveda 2013, 34(1):90-94.

30. Nadkarni KM: Indian Materia Medica, Vol 1. Mumbai: Popular Prakashan; 1982:729.

31. Nagalapur SK, Paramjyothi S: In vitro antioxidant activity of launaea pinnatifida cass leaves. Biogeosciences 2010, 5(1):105-108.

32. Pullaiah T: Encyclopedia of world medicinal plants. Regency 2006, 1:1217.

33. Arun AB, Beena KR, Raviraja NS, Sridhar KR: Coastal sand dunes-a neglected ecosystem. http://www.ias.ac.in/currsci/jul10/articles9.htm.

34. Kirtikar KR, Basu BD: Indian Medicinal plants,Vol II. New Delhi: Periodical Experts Book Agency; 1975

35. Jain SK, Srivastava S: Traditional uses of some Indian plants among islanders of the Indian Ocean. Indian J Tradit Knowl 2005, 4:345-357.

36. Blasco F, Aizpuru M, Gers C: Depletion of the mangroves of continental Asia. Wetl Ecol Manag 2001, 9:245-256.

37. Behera DP, Nayak L: Floral Diversity of Bhitarkanika, East Coast of India and its potential uses. J Chem Biol Phys Sci 2013, 3(3):1863-1874

38. Weber-El G, Magda O: The systematic relationships of Aegialitis (Plumbaginaceae) as revealed by pollen morphology. Plant Syst Evol 1984 144(1):53-58.

39. Aegialitis: Flora Conservation and Herbarium Program: FloraBase. Department of Environment and Conservation, Government of Western Australia; 2009.

40. Vane JR: The evolution of non-steroidal ant-inflammatory drugs and their mechanisms of action. Drugs 1987, 33:18-27. 
41. Moltz H: Fever: causes and consequences. Neurosci Biobehav Rev 1993, 17(3):237-269.

42. Devi BP, Boominathan R, Mandal SC: Evaluation of antipyretic potential of Cleome viscosa Linn. (Capparidaceae) extract in rats. J Ethnopharmacol 2003, 87(1):11-13.

43. Akio $\mathrm{M}$, Tomoki $\mathrm{N}$, Tatsuo $\mathrm{W}$ : Pattern differences in experimental fevers induced by endotoxin, endogenous pyrogen and prostaglandins. Am J Physiol 1988, 254(4 Pt 2):R633-R640.

44. Cody V, Middleton E, Harborne JB: Plant Flavonoids in Biology and Medicine. New York: Biochemical, Pharmacological and Structure - Activity Relationships, Alan R.Liss; 1986:521-536.

45. Mutalik S, Paridhavi K, Mallikarjuna Rao C, Udupa N: Antipyretic and analgesic effect of leaves of Solanum melongena Linn in rodents. Indian J Pharmacol 2003, 35:312-315.

46. Singh S, Majumdar DK: Analgesic activity of Ocimum sanctum and its possible mechanism of action. Int J Pharmacogn 1995, 33:188-192.

47. Deraedt R, Jouquey S: Inhibition of prostaglandin biosynthesis by nonnarcotic analgesic drugs. Arch Int Pharmacodyn Ther 1976, 224(1):30-42

48. Collier HOJ, Dinneen JC, Johnson CA, Schneider C: The abdominal constriction response and its suppression by analgesic drugs in the mouse. Br J Pharmacol Chemother 1968, 32:295-310.

49. Kim HP, Son KH, Chang HW, Kang SS: Anti-inflammatory plant flavonoids and cellular action mechanism. J Pharmacol Sci 2004, 96:229-245.

50. Jensen TS, Yaksh TL: Comparison of antinociceptive action of morphine in the periaqueductal gray, medial and paramedial in rat. Brain Res 1986, 363:99-113

51. Grumbach L: The production of analgesic activity in man by animal testing. In Edited by Knighton RS, Dumke PR. Boston: Pain, Little Brown and Co; 1966:163-182

52. Sannigrahi S, Mazumder UK, Pal D, Mishra ML, Maity S: Flavonoids of Enhydra Fluctuans exhibits analgesic and anti-inflammatory activity in different animal models. Pak J Pharm Sci 2011, 24(3):369-375.

53. Jäger AK, Saaby L: Flavonoids and the CNS. Molecules 2011, 16:1471-1485.

54. Dirosa M, Giroud JP, Willoughby DA: Studies of the acute inflammation response induced in rats in different sites by carrageenan and turpentine. J Pathol 1971, 104:15-29.

55. Winter CA, Risley EA, Nuss GW: Carrageenin-induced edema in hind paw of the rat as an assay for anti-inflammatory drugs. Proc Soc Exp Biol Med 1962, 111:544-547.

56. Mossa JS, Rafatullah S, Galal AM, Al-Yahya MA: Pharmacological studies of Rhus retinorrhaea. Int J Pharmacog 1995, 33:242-246.

57. Saha A, Ahmed M: The analgesic and anti-inflammatory activities of the extract of albizia lebbeck in animal model. Pak J Pharm Sci 2009, 22(1):74-77.

58. Dunne MW: Pathophysiology: "Concepts of altered Health States with Contributors". In Philadelphia: Porth C.M., Lippincott eds; 1990:165-176.

59. Arrigoni-Maratellie E: Inflammation and Anti-inflammatory. In New York: Spectrum Publication Inc; 1988:119-120.

60. Swingle KF, Shideman FE: Phases of the inflammatory response to subcutaneous implantation of a cotton pellet and their modification by certain anti-inflammatory agents. J Pharmacol Exp Ther 1972, 185:226-234.

61. Recio MC, Giner RM, Manez S, Ros JL: Structural requirements for the antiinflammatory activity of natural triterpenoids. Med 1995, 6:182-185.

62. Owoyele VB, Adediji JO, Soladoye AO: Anti-inflammatory activity of aqueous leaf extract of Chromolaena odorata. Inflammopharmacology 2005, 13(5-6):479-484

63. Dahanukar SA, Kulkarni RA, Rege NN: Pharmacology of medicinal plants and natural products. Indian J Pharmacol 2000, 32:581-s118.

64. OECD: OECD guidelines for testing of chemicals 423: Acute oral toxicityacute toxic class method. 2001.

65. Mehdi H, Tan GT, Pezzuto JM, Fong HH, Farnsworth NR, El-Feraly FS: "Cell culture assay system for the evaluation of natural product mediatedantihepatitis B virus activity". Phytomedicine 1997, 3:369-377.

66. Adams SS, Hebborn P, Nicholson JS: Some aspects of the pharmacology of ibufenac, a non-steroidal anti-inflammatory agent. J Pharm Pharmaceut 1968, 20:305-312.

67. Luiz CDS, Mirtes C, Sigrid LJ, Mizuekirizawa M, Cecilia G, Jrotin G: Screening in mice of some medicinal plants used for analgesic purposes in the state of SãO Paulo. J Ethnopharmacol 1988, 24(2-3):205-211.

68. Mukkamala SK, Ramana KV, Rambabu P, Borra PK: Pharmacognosy of medicinal plants and natural products. Int J Phamacol Bio/ Sci 2010, 4:71.
69. Koster R, Anderson M, De Beer EJ: Acetic acid analgesic screening. Fed Proc 1959, 18:418-420.

70. Hendershot LC, Forsaith J: Antagonism of the frequency of phenylquinoneinduced writhing in the mouse by weak analgesics and nonanalgesics. J Pharmacol Exp Ther 1959, 125:237-240.

71. Winter CA, Porter CC: Effect of alteration in side chain upon antiinflammatory and liver glycogen activities of hydrocortisone ester. J Am Pharma Ass Sci 1957, 46:515-519.

72. Turner RA: Screening Methods in Pharmacology. In Edited by Turner RA. New York: Academic Press; 1965:158.

doi:10.1186/0717-6287-47-55

Cite this article as: Raju et al:: Assessment of pharmacological activities of two medicinal plant of Bangladesh: Launaea sarmentosa and Aegialitis rotundifolia roxb in the management of pain, pyrexia and inflammation. Biological Research 2014 47:55.

\section{Submit your next manuscript to BioMed Central and take full advantage of:}

- Convenient online submission

- Thorough peer review

- No space constraints or color figure charges

- Immediate publication on acceptance

- Inclusion in PubMed, CAS, Scopus and Google Scholar

- Research which is freely available for redistribution 